\title{
BELÉM: URBANIZAÇÃO REGIONAL POLICÊNTRICA E CIDADE-REGIÃO
}

\author{
Willame de Oliveira Ribeiro \\ Universidade do Estado do Pará - UEPA \\ Programa de Pós-Graduação em Geografia, Belém, PA, Brasil \\ willame@uepa.br
}

\begin{abstract}
RESUMO
Os objetivos do artigo consistem em analisar as concepções de cidade-região e urbanização regional policêntrica no âmbito do debate sobre as morfologias urbano-regionais e reconhecer os principais elementos da realidade urbano-regional configurada, nas últimas décadas, a partir de Belém, capital do Estado do Pará, no norte do Brasil. Mediante o desenvolvimento de procedimentos metodológicos como levantamentos bibliográficos e documentais, bem como trabalhos de campo, constatou-se que há razoável disseminação das morfologias urbanoregionais no mundo atual, com manifestação, inclusive, em realidades precárias como a de Belém, onde se registram fatores do processo de urbanização regional policêntrica e de sua forma espacial, a cidade-região, como: diversidade de renda e de tipos de assentamentos dos grupos sociais nas antigas e novas áreas dispersas; dispersão dos espaços de consumo; ampliação da escala da dispersão e da configuração das novas periferias; e fortalecimento de outras centralidades (além do núcleo metropolitano) e, conseguinte, diversificação e complexificação dos fluxos.
\end{abstract}

Palavras-chave: Urbanização regional policêntrica. Cidade-região. Belém do Pará.

\section{BELÉM: POLYCENTRIC REGIONAL URBANIZATION AND CITY-REGION}

\begin{abstract}
The objectives of this article are to analyze the conceptions of city-region and polycentric regional urbanization in the context of the debate on urban-regional morphologies and recognize the main elements of the urban-regional reality configured, in recent decades, from Belém, capital of the State of Pará, in northern Brazil. Through the development of methodological procedures such as bibliographic and documentary surveys, as well as fieldwork, it was contacted that there is reasonable dissemination of urban-regional morphologies in the current world, with manifestation, including, in precarious realities such as that of Belém, where factors of the polycentric regional urbanization process and its spatial form are recorded, the city-region, such as: diversity of income and types of settlement of social groups in the old and new dispersed areas; dispersion of consumption spaces; expansion of the dispersion scale and configuration of the new peripheries; and strengthening of other centralities (besides the metropolitan nucleus) and, consequently, diversification and complexification of flows.
\end{abstract}

Keywords: Polycentric regional urbanization. City-region. Belém do Pará.

\section{INTRODUÇÃO}

As morfologias urbano-regionais apresentam-se enquanto as mais complexas formas espaciais a comporem a rede urbana atual. E nem por isso são raras, ao contrário, estão cada vez mais presentes nas mais diversas realidades do mundo de hoje. Acompanhando essa difusão, uma infinidade de nomenclaturas surgiu para interpretá-las, muitas delas coerentes e originadas a partir de autores e obras de grande relevância.

Neste texto, o foco recai sobre a concepção de cidade-região, inserida nesse quadro, associada ao processo de urbanização regional policêntrica (SOJA, 2013). Assim, articuladas, como processo e forma, as duas concepções, após sua devida explanação, serão aplicadas à interpretação da realidade concreta de Belém do Pará, capital do Estado do Pará, que constitui uma forma-conteúdo urbano-regional de notável importância na Amazônia brasileira, conformando uma área de influência extremamente vasta e que suplanta os próprios limites estaduais.

Caminhos de Geografia $\quad$ Uberlândia-MG $\quad$ v. 22, n. $80 \quad$ abr./2021 $\quad$ p. 97-118 Página 97


Os objetivos do artigo são, num primeiro momento, analisar, de um ponto de vista teórico, as concepções de cidade-região e urbanização regional policêntrica no âmbito do debate sobre as morfologias urbanoregionais e, num segundo momento, numa ótica empírica e utilizando-se dessas ferramentas conceituais, reconhecer os principais elementos da realidade urbano-regional configurada, nas últimas décadas, a partir de Belém do Pará.

No que se refere aos procedimentos metodológicos, é oportuno salientar que esse artigo resulta de um conjunto de projetos desenvolvidos desde 2013 , a começar pela tese de doutoramento que refletia sobre as particularidades de cidades de expressão regional no nordeste paraense e suas interações espaciais, 0 que acabou levando ao reconhecimento de uma delas, Castanhal, como integrante de uma forma urbanoregional conformada a partir de Belém. Após isso, entre 2017 e o presente, o desenvolvimento de três projetos de pesquisa também contribuíram com essas reflexões por abordar problemáticas inseridas no contexto aqui discutido. Também cabe o registro das contribuições advindas dos debates realizados no âmbito do Grupo de Pesquisa Geografia do Pará Urbano - GeoPUrb, que integra a estrutura do Programa de Pós-Graduação em Geografia da Universidade do Estado do Pará - PPGG/UEPA.

Essas pesquisas que subsidiaram os resultados aqui expostos tiveram como instrumentos principais, além do levantamento e análise de material bibliográfico condizente com o objeto de investigação, a realização de:

a) Levantamentos documentais sobre a formação socioespacial de Belém e dos demais municípios integrantes da cidade-região, bem como sobre o quadro populacional, econômico e de interações espaciais da área de estudo e, nesse sentido, especial importância tiveram os dados provenientes do Instituto Brasileiro de Geografia e Estatística - IBGE, especialmente dados dos Censos Demográficos Brasileiros de 2000 e 2010 e os estudos Regiões de Influência das Cidades REGIC 2018 (IBGE, 2020) e Divisão Urbano Regional (IBGE, 2013);

b) Trabalhos de campo voltados à observação dirigida, ao levantamento de informação para elaboração de mapas, ao contato com sujeitos da pesquisa e à realização de entrevistas.

O texto está estruturado em três seções, sendo a primeira voltada ao plano teórico, com o debate do processo de urbanização regional policêntrica e da concepção de cidade-região no âmbito das morfologias urbano-regionais. As duas últimas seções voltam-se à realidade concreta de Belém do Pará, apresentando, a partir de materiais bibliográficos e documentais, a formação metropolitana de Belém, e, na sequência, a sua conformação enquanto cidade-região, com base nos diversos procedimentos imersos nos trabalhos de campo.

\section{A URBANIZAÇÃO REGIONAL POLICÊNTRICA COMO PROCESSO E A CIDADE-REGIÃO COMO FORMA}

A crescente imbricação entre a escala do espaço urbano e a escala regional tem sido um grande traço da urbanização contemporânea, especialmente, daqueles espaços dotados de maior complexidade, isto é, condizentes com as realidades urbanas mais densas, diversas e relevantes no âmbito da rede urbana. Em resposta a isso, nos últimos anos, a produção científica especializada tem formulado um número expressivo de conceitos cujo cerne está nessa sobreposição entre a cidade e a região.

Objetivando esclarecer e comparar as diversas abordagens, Moura (2009) construiu um quadro síntese reunindo algumas das principais terminologias usadas para se referir ao que ela denominou de morfologias urbano-regionais, bem como as obras e autores que estão na sua origem e as principais características de cada proposição. A partir dessa organização e procedendo adaptações, bem como acréscimos de contribuições de autores brasileiros, inclusive, da formulação de Moura 
(2009), constituiu-se o quadro 1, com algumas das propostas mais relevantes inseridas nesse contexto de leituras teóricas pautadas na articulação urbano-regional.

Quadro 1 - Morfologias urbano-regionais, referências e breve descrição.

\section{Morfologia Referência Descrição}

\begin{tabular}{|c|c|c|}
\hline Megalópole & Gottman (1970) & $\begin{array}{c}\text { Contínuo urbano de centenas de quilômetros, superando os } 20 \\
\text { milhões de habitantes, originado pelo crescimento de uma cidade } \\
\text { até o contato com a região de influência de outra cidade, pela } \\
\text { concentração de atividades e população, favorecido pelos novos } \\
\text { meios de comunicação e transporte. }\end{array}$ \\
\hline Megarregião & Sassen (2007) & $\begin{array}{c}\text { Território diverso onde coexistem múltiplos tipos de economias de } \\
\text { aglomeração, atualmente distribuídos entre diversos espaços } \\
\text { econômicos e escalas geográficas; uma única megazona } \\
\text { econômica. }\end{array}$ \\
\hline $\begin{array}{c}\text { Cidade } \\
\text { dispersa }\end{array}$ & $\begin{array}{l}\text { Monclús } \\
(1998) ; \\
\text { Dematteis } \\
\text { (1998) }\end{array}$ & $\begin{array}{l}\text { Processo de criação de novos assentamentos urbanos próximos às } \\
\text { grandes cidades ou a grandes vias de comunicação } \\
\text { (periurbanização e suburbanização), com uma morfologia difusa, } \\
\text { seletiva, como uma "desconcentração concentrada". }\end{array}$ \\
\hline Metápole & $\begin{array}{c}\text { Ascher (1998 } \\
[1995])\end{array}$ & $\begin{array}{c}\text { Tem origem num processo de metropolização "metastásica”, em } \\
\text { territórios não-contíguos e não metropolitanos; de espaços } \\
\text { "metropolizados" cujo conjunto ultrapassa e engloba as zonas } \\
\text { metropolitanas stricto sensu, desenvolvendo-se de maneira } \\
\text { anárquica, não hierarquizada. }\end{array}$ \\
\hline $\begin{array}{c}\text { Cidade-região } \\
\text { global }\end{array}$ & $\begin{array}{l}\text { Scott; Agnew; } \\
\text { Soja; Storper } \\
\quad(2001)\end{array}$ & $\begin{array}{c}\text { Nós espaciais articulados globalmente por seus arranjos de } \\
\text { governança, funcionando como plataformas territoriais a partir das } \\
\text { quais empresas disputam mercados globais. }\end{array}$ \\
\hline Pós-metrópole & $\begin{array}{c}\text { Soja (2008 } \\
[2000])\end{array}$ & $\begin{array}{c}\text { Sintetiza a ruptura da lógica socioespacial da metrópole baseada em } \\
\text { uma aglomeração física para um espaço descontínuo, um } \\
\text { "fenômeno poliédrico", decorrente da desindustrialização e } \\
\text { reindustrialização e da desconcentração e reconcentração das } \\
\text { nodalidades urbanas. }\end{array}$ \\
\hline $\begin{array}{l}\text { Arranjos } \\
\text { urbano- } \\
\text { regionais }\end{array}$ & Moura (2009) & $\begin{array}{c}\text { Formas urbanas complexas, multidimensionais e transescalares, } \\
\text { que extrapolam a cidade enquanto forma física, incorporam formas } \\
\text { nem sempre contínuas de aglomerações urbanas mais extensas e } \\
\text { polarizam, em nível regional, diretamente um território que } \\
\text { transcende o aglomerado principal e onde estão outras } \\
\text { aglomerações. }\end{array}$ \\
\hline $\begin{array}{l}\text { Região pós- } \\
\text { metropolitana }\end{array}$ & Lencioni (2017) & $\begin{array}{c}\text { Resultado do processo de metropolização regional policêntrica, } \\
\text { diferenciando-se da região metropolitana característica do fordismo } \\
\text { e contendo muitas escalas superpostas e entrelaçadas (local, } \\
\text { regional, nacional e global). }\end{array}$ \\
\hline
\end{tabular}

Moura (2009), apesar de discorrer sobre essas várias nomenclaturas para se referir a formas urbanas com expressão regional, propõe um novo termo: 'arranjos urbano-regionais'. Estes seriam resultados do processo de metropolização vigente no Brasil, cumprindo importante papel concentrador de atividades econômicas, população, serviços, tecnologia etc., configurando-se como principais centros da rede urbana. Essa forma urbana é dotada de complexidade bem maior que as aglomerações urbanas tradicionais (com uma clara estruturação a partir de polo e periferias), alcançando uma escala regional. 
Todavia, a autora constata que, para os casos de Belém, Manaus e Fortaleza, a concepção de arranjos urbano-regionais não se aplicaria, pois estes ainda comporiam "[...] formas simples, expressas na extensão dos polos e conformação de periferias, sem a aglutinação de centros ou aglomerações vizinhas [...]", mesmo apresentando "[...] uma abrangência regional de polarização [...]" (MOURA, 2009, p.106). Em seguida, ressalta que os arranjos urbano-regionais "[...] não demarcam limites precisos, são polarizados pela principal metrópole regional, salvo exceções, e trazem em sua composição conjuntos de centralidades expressivas, categorizadas como capitais regionais e centros sub-regionais".

Apesar deste trabalho não adotar a terminologia arranjo urbano-regional, mas levando em conta as afinidades desse conceito com a realidade percebida em Belém, considera-se que, para o caso de Belém, as conclusões de Moura são questionáveis diante do que será aqui apresentado, especialmente, quando se toma, além do espaço metropolitano de Belém, a cidade de Castanhal, uma capital regional com razoável complexidade e importância no âmbito da formação socioespacial amazônica, como parte de um mesmo conjunto.

Com certa facilidade, reconheceríamos uma série de aproximações entre a realidade do espaço metropolitano de Belém e seu entorno e as diversas nomenclaturas utilizadas para se referir às morfologias urbano-regionais, o que, por si só, já sugere o alcance dessa condição por Belém. Não obstante, entende-se, aqui, que o termo cidade-região, bem como o processo que lhe dá existência, a urbanização regional (SOJA, 2013), são dotados de maior coerência com a realidade em questão, conforme tentar-se-á demonstrar, em termos teóricos, nos próximos parágrafos, e empíricos, mais adiante.

A multiplicação de importantes análises a respeito das morfologias urbano-regionais, em geral acompanhadas de uma nomenclatura própria, mesmo elas possuindo muito mais semelhanças que distinções entre si, atestam a disseminação dessas realidades pelo mundo, indicando este ser o caminho tomado pelo processo de urbanização em seus espaços mais complexos, as metrópoles, isto é, nas mais diversas partes do mundo as metrópoles tem alcançado patamares superiores de complexidade, fazendo com que este conceito, metrópole, bem como o processo que está em seu cerne, a metropolização, não sejam mais suficientes para abarcar os agentes, os processos e as formas que hoje lhes dão concretude.

Apesar de esperada, diante das incertezas e da juventude dessas realidades, a multiplicidade de conceitos se referindo a situações aproximadas, mesmo com referências empíricas distanciadas, pode se tornar um empecilho ao alcance de melhores níveis de compreensão. Desse modo, não se pretende aqui anunciar um novo conceito ou expressão, mas, dentre as relevantes leituras existentes, reconhecer aquela mais promissora para a análise de Belém e de seu entorno, no Estado do Pará.

Assim, propõe-se a interpretação do espaço em questão mediante as concepções de urbanização regional policêntrica (SOJA, 2013), enquanto processo, e cidade-região (SCOTT, AGNEW, SOJA, STORPER, 2001; DELGADO 2003; LENCIONI 2006; MAGALHÃES, 2008), como forma. Certamente, tanto o processo quanto a forma estão muito mais bem configurados em outros espaços, como a realidade de Los Angeles, nos Estados Unidos, locus principal das reflexões de Edward Soja. No entanto, podem ser reconhecidas uma série de indicadores na realidade de Belém que a aproximam dessas conceituações ou, no mínimo, evidenciam transformações nessa direção.

Além disso, como será tratado mais adiante, o par urbanização regional/cidade-região revela algumas vantagens sobre o mais comumente trabalhado no Brasil, metropolização/espaços metropolitanos ou metropolizados. Principalmente porque o primeiro evidencia a multiplicidade de tipos de centros e de origens dos processos, o que, normalmente, apesar de se argumentar o contrário, nas abordagens centradas na metropolização não ocorre, pois as metrópoles são, explícita ou implicitamente, tomadas como origem de quase tudo de relevante que se sucede em termos de produção do espaço e modificações no modo de vida.

Soja (2008 [2000]) já argumentava sobre os limites da urbanização metropolitana para explicar diversos novos espaços configurados nos últimos anos a partir das metrópoles. Foi o que denominou, provisoriamente, de transição pós-metropolitana, diante da consciência de que mudanças muito importantes ocorriam, mas, ao mesmo tempo, ainda imperava a impossibilidade de reconhecimento mais claro sobre aquilo que estava em construção. É isso que representa a expressão "pósmetrópole", um reconhecimento parcial dos novos rumos do processo de urbanização. Mais tarde, em Soja (2013), as convicções sobre esses rumos estavam bem mais sedimentadas:

Caminhos de Geografia Uberlândia-MG $\quad$ v. 22, n. $80 \quad$ abr./2021 $\quad$ p. 97-118 Página 100


Hoje estou convencido de que o que tem acontecido com as cidades ao longo dos últimos trinta anos pode ser mais bem descrito como uma mudança paradigmática na verdadeira natureza do processo de urbanização. Embora ainda em seus estágios primários, o processo de urbanização regional avançou o suficiente em algumas áreas metropolitanas para que as suas características definidoras fossem reconhecidas e analisadas, e para que os estudiosos urbanos começassem a entender que a era da metrópole moderna pode estar terminando, criando uma crescente necessidade de novas estruturas para a compreensão e estudo das cidades e geografias urbanas (pp.150-151).

De acordo com Soja (2013), a urbanização metropolitana ainda resguardava muito do centralismo que marcava sua fase anterior, a do urbanismo industrial centralizado. Por sua vez, a urbanização regional é assinalada por uma similaridade entre as densidades das áreas urbanas e suburbanas, diminuindo as diferenças entre o núcleo da então metrópole e outras áreas centrais compostas ao longo da área particularizada pelo processo de urbanização regional.

Os subúrbios, além de mais densos, também se transmudam mais complexos e diferenciados, assemelhando-se ao núcleo metropolitano, ou seja, convertem-se cada vez mais urbanizados, ao passo que, "[...] a metrópole monocêntrica moderna se metamorfoseia em uma cidade regional policêntrica, abrangendo uma rede amplamente distribuída de aglomerações de variados tamanhos [...]" (SOJA, 2013, p.154).

A urbanização regional policêntrica, como qualificada por Soja (2013), tem como um de seus resultados a concepção de uma morfologia urbana transescalar, promovendo uma complexa convergência entre aquilo que se convencionou chamar de espaço intraurbano, ou simplesmente espaço urbano, e a região, dando origem e disseminando as cidades-região ou cidades regionais. Nas palavras de Soja (2013, p.157):

As escalas urbana, metropolitana e regional subnacional parecem estar se amalgamando em muitas partes do mundo, resultando no surgimento do que alguns agora chamam de regiões de megacidades, megarregiões, regiões megalopolitanas, galáxias regionais ou mesmo regiões-Estado, imensas redes regionais de aglomerações.

Desse modo, Soja (2013) reconhece o processo de urbanização regional policêntrica como aquele por trás das morfologias urbano-regionais, cujas nomeações diversas proliferaram no âmbito da literatura acadêmica nos últimos anos. Para fins desse trabalho, será adotado o termo "cidaderegião", por se entender que ele é o que mais denota coerência com o citado processo.

Diversos autores têm se ocupado nos últimos anos com o exame das cidades-região. Nem sempre para se referir ao mesmo fenômeno. Klink (2001), por exemplo, não apresenta grande preocupação com o esclarecimento do conceito (seus esforços se voltam mais à reestruturação produtiva do $A B C$ Paulista e às problemáticas associadas à gestão local) e define as cidades-região como áreas metropolitanas que superam um milhão de habitantes, "[...] cuja delimitação administrativa e institucional nem sempre coincide com a sua identidade política e econômica, e que estão inseridas nos processos globais de transformação econômica" (KLINK, 2001, p.7).

É questionável uma abordagem centrada no conceito de cidade-região que se detenha tão diretamente à análise de um recorte, como é o $A B C$ Paulista, de uma forma urbana bem mais ampla, o espaço metropolitano de São Paulo. Claramente, a concepção de cidade-região é mais coerente na referência à totalidade do espaço metropolitano da capital paulista.

Para Delgado (2003) a cidade-região seria constituída por três subespaços: 1) área urbana conurbada - espaço metropolitano em si, isto é, aquele que evidencia, com clareza, os elementos definidores da metrópole em termos de densidade, diversidade e complexidade econômica, política, cultural etc.; 2) coroa regional - espaço periurbano próximo, não conurbado, no qual se dão as dinâmicas de difusão econômica, social e urbana; 3) periferia regional - espaço onde não se manifesta os processos de difusão. A coroa regional contém as mais relevantes aglomerações do entorno metropolitano e, segundo Delgado (2003, p.44), seria 
[...] o primeiro contorno não conurbado de uma cidade-região (assim sua urbanização é fragmentária) é o âmbito ad hoc para a descentralização intrarregional (assim é muito dinâmica) e é lugar "dobradiça" [...] onde se concentra uma mudança de escala entre o regional e o metropolitano (assim é necessário analisar ambas as escalas). Por todos esses motivos, na coroa regional reside o principal potencial de reestruturação da cidade-região a que pertence. ${ }^{1}$

Dando prosseguimento às análises realizadas em Ribeiro (2017, 2018), aqui manifesta-se uma grande concordância com os postulados de Delgado a respeito da composição da cidade-região, reconhecendo a existência de importantes diferenciações internas bem como uma unidade consubstanciada nos fluxos e, portanto, no caráter relacional do espaço. Leitura corroborada por Lencioni (2006, p.72), ao considerar a cidade-região como produto do processo de metropolização do espaço, que, em algumas metrópoles,

[...] tanto renova suas áreas urbanas como estende sua área territorial por meio da incorporação de cidades, formando um novo aglomerado metropolitano que se constitui num verdadeiro epicentro de fluxos de capitais, onde a densidade das redes territoriais encontra maior densidade e complexidade. Ao mesmo tempo, há alterações nas centralidades urbanas e redefinições das funções do núcleo metropolitano [...]. Por outro lado, há uma grande transformação nas cidades pequenas e médias do entorno metropolitano que passam a apresentar hábitos culturais e representações de valores urbanos que até então eram exclusivos ao viver nas metrópoles.

Na mesma linha de raciocínio, Magalhães (2008) argumenta que a cidade-região seria uma forma contemporânea do processo de metropolização, possuindo tanto continuidades quanto descontinuidades em relação aos processos pretéritos. Mais que uma metrópole estendida, a cidaderegião ganharia concretude no momento em que "[...] o processo de urbanização dos entornos metropolitanos começa a se intensificar e a ter suas lógicas integradas ao tecido metropolitano, através de um aumento também dos fluxos do núcleo metropolitano para o seu entorno e vice-versa" (MAGALHÃES, 2008, p.11). Nesse sentido, o espaço relacional e as descontinuidades no espaço físico seriam centrais na caracterização dessa forma urbana, definida como "[...] a área metropolitana mais concisa somada de seu entorno imediato, incluindo uma série de centralidades de pequeno e médio porte no alcance dos processos de metropolização" (MAGALHÃES, 2008, p.9).

Com algumas poucas modificações, adota-se aqui a proposição de Magalhães. O que ele nomeou de "área metropolitana concisa" recebe neste trabalho a denominação de espaço metropolitano, isto é, um espaço cujos sistemas de objetos e os sistemas de ações (SANTOS, 2009) são densos, multifacetados e articulados de forma diferenciada dos outros espaços. Da mesma forma, o entorno imediato não é considerado parte do espaço metropolitano, porém articulado com ele.

Nesses moldes, assim como definido em Ribeiro (2017, 2018), a cidade-região abrange tanto o espaço metropolitano quanto o entorno diretamente a ele articulado, constituindo uma morfologia urbano-regional de caráter relacional, na qual a contiguidade física não se conforma como fator preponderante.

Sob a denominação de cidade-região encontram-se uma grande diversidade de realidades, das que evidenciam papéis em nível regional, como Belém, àquelas que desenvolvem conexões profundas e funções fundamentais para a economia global, as cidades-regiões globais de Scott; Agnew; Soja; Storper (2001), que funcionariam como nós espaciais e atores políticos no mundo globalizado. Mas

\footnotetext{
1 No original: "[...] el primer contorno no conurbado de una ciudad-región (por lo que su urbanización es fragmentaria), es el ámbito ad hoc para la descentralización intrarregional (por lo que es muy dinámica) y es lugar "gozne" o "bisagra" en donde se concentra un cambio de escala entre lo regional y lo metropolitano (por eso es necesario analizar ambas as escalas a la vez). Por todos estos motivos, en la corona regional reside el principal potencial de reestructuración de la ciudad-región a la que pertenece.
}

Caminhos de Geografia Uberlândia-MG $\quad$ v. 22, n. $80 \quad$ abr./2021 $\quad$ p. 97-118 Página 102


nem todas as cidades-regiões estão tão profundamente inseridas na cena global. Segundo os autores anteriormente citados:

Existem hoje mais de 300 cidades-regiões no mundo com populações de mais de um milhão de habitantes. Pelo menos vinte cidades-regiões abrigam mais de dez milhões de pessoas. Estas variam desde aglomerações metropolitanas comuns dominadas por um núcleo muito desenvolvido, como a região de Londres ou Cidade do México, até unidades geográficas mais policêntricas como no caso das redes urbanas da Randstad ou Emilia-Romagna (SCOTT; AGNEW; SOJA; STORPER, 2001, p.11)

Mediante esse apanhado a respeito das morfologias urbano-regionais e, principalmente, pautando-se na concepção de urbanização regional policêntrica (SOJA, 2013) e de cidade-região, forma urbana discutida de forma relevante por diversos autores, como aqui já demonstrado; na sequência do texto, faz-se o exame da realidade concreta de Belém, capital do Estado do Pará, e de seu entorno, que nos últimos anos tem cada vez mais reforçado sua condição urbano-regional.

\section{BELÉM: DE CIDADE PRIMAZ À METRÓPOLE}

Antes de tratar diretamente da manifestação do processo de urbanização regional de Belém e da constituição da morfologia da cidade-região, cabem alguns comentários a respeito da formação socioespacial de Belém e dos seus papéis regionais.

Belém foi fundada pelos portugueses em 1616, mediante a instalação do Forte do Presépio, a partir do qual dá-se a expansão da cidade. Segundo Corrêa (2006), Belém cumpria, no século XVII, uma dupla função: defesa do território e ponto para penetração no espaço amazônico. Diversos núcleos de povoamento foram criados na Amazônia, nesse período, a partir de Belém, o que permite uma primeira constatação: Belém desde os seus primórdios cumpre papéis em nível regional, mesmo quando não passava de um incipiente núcleo urbano, pois, como relata Sarges (2010, p.70), "até a primeira metade do século XVII, a população de Belém se resumia a 80 moradores, excluindo os religiosos, militares e nativos, e algumas construções modestas, entre elas, duas igrejas". Essa constatação também está presente em Moreira (1966, p.164), quando expõe que "Belém manifestou desde cedo uma certa 'pinta' de grandeza, fruto sem dúvida de um conjunto de vantagens geográficas e históricas, que a credenciaram para a função metropolitana que sempre exerceu na Amazônia".

Essa ocupação vai gradativamente se ampliando até conhecer um significativo crescimento a partir de 1751, quando Belém torna-se a sede da Província do Grão-Pará e Maranhão, já que "[...] com o Governo-Geral, vieram alguns auxiliares com suas famílias e outros elementos vinculados ou não à administração" (SARGES, 2010, p.78). Esse já é o contexto das políticas do Marquês de Pombal, cujas ideias modernizadoras, inclusas naquilo que se convencionou denominar despotismo esclarecido, tiveram grande repercussão na Amazônia, especialmente em Belém, que ratifica sua primazia na rede urbana regional (CORRÊA, 2006), cada vez mais tipificada enquanto uma rede urbana dendrítica², no âmbito da qual desempenhava o papel de cidade primaz.

No período de 1850 a 1920, com o chamado "boom" da borracha, a rede urbana se torna mais complexa, com o surgimento e o fortalecimento de outros centros urbanos, no entanto, Belém ratifica

2 Forma simples da rede urbana, com origem colonial, pressupõe a "criação de uma cidade estratégica e excentricamente localizada face a uma futura hinterlândia. Esta cidade, de localização junto ou próximo ao mar, é o ponto inicial de penetração e conquista do território à sua retaguarda, e sua porta de entrada e saída" (CORRÊA,1989, p. 72). Estão entre as principais características da rede urbana dendrítica, segundo Corrêa: uma cidade primaz que concentra a maior parte do comércio atacadista exportador e importador, da renda e do mercado de trabalho; grande número de pequenos centros urbanos; e ausência ou insuficiência de centros intermediários. 
sua influência regional e passa por um forte processo de modernização. Trindade Júnior (1998, p.100) assim resume as diversas transformações no espaço urbano de Belém nesse período:

\begin{abstract}
- Grande crescimento populacional e expansão urbana significativa.
- Investimentos em infra-estrutura (sistema viário, arruamentos, cais, calçamentos, abastecimento de água, iluminação, etc.), equipamentos (teatros, hospitais, mercados, matadouros, transportes coletivos, repartições públicas, etc.), serviços (limpeza, corpo de bombeiros, etc.) e embelezamento urbano (praças, bosques, arborização, etc.), com forte influência europeia (Belle Époque).
\end{abstract}

- Especialização funcional do centro comercial: maior número de lojas, bancos, consulados, etc.

- Maior segregação sócio-espacial e diversificação das localizações: sofisticadas residências nos bairros de Nazaré, Batista Campos e Umarizal.

- Setor secundário embrionário (bairros do Comércio e Reduto).

- Melhoramentos urbanos de caráter essencialmente elitista, principalmente na gestão de Antônio Lemos, com assessoria de técnicos estrangeiros especializados.

- Projeção e expansão urbana para os bairros do Marco e Pedreira.

As numerosas novidades em Belém dão conta da grande importância desse período na produção do espaço urbano da atual capital do Estado do Pará, acompanhando a relevância econômica da borracha, que "[...] chegou a rivalizar com o café na contribuição à entrada de divisas no país" (PORTO-GONÇALVES, 2008, p.88).

Em termos da rede urbana, segundo Corrêa (2006), a grande demanda pela borracha no mercado internacional inseriu a Amazônia na Divisão Internacional do Trabalho e trouxe grandes consequências para a rede urbana regional como: criação de novos núcleos urbanos e revigoramento dos preexistentes através do crescimento demográfico e econômico; intensificação, por meio do sistema de aviamento, das relações entre os núcleos; grande crescimento, modernização e reforço da centralidade das cidades de Belém e Manaus na rede urbana regional, que alcança o ápice de sua forma dendrítica.

No caso específico de Belém, além dos melhoramentos urbanos já citados e que até o presente marcam a cidade, um outro aspecto merece menção, um primeiro movimento de dispersão urbana com características bastante particulares. Trata-se da constituição, por parte de segmentos da elite de Belém, de segundas residências nos arredores da cidade, voltadas a fins de lazer e descanso, seguindo costume disseminado na cidade pelos estrangeiros envolvidos na modernização urbana financiada pela economia da borracha. A finalidade mais específica dessas residências acabava por produzir fluxos principalmente semanais e não movimentos pendulares, normalmente designadores dos processos mais comuns de dispersão urbana.

Espaços como Mosqueiro, Vila Pinheiro (Icoaraci) e áreas próximas a Belém, no trajeto da Estrada de Ferro de Bragança, são exemplos desse processo de dispersão. O trecho de Meira Filho (1978, pp.44-45) evidencia isso na llha de Mosqueiro:

O Mosqueiro tornar-se-ia, durante longo período, abrigo de raras personalidades estrangeiras que procuravam, ali, respirar melhor e deleitar-se com as belezas do lugar. Poucos nacionais, paraenses, mesmo, deixariam Belém em busca das praias da llha. Somente no fim do século passado e no começo do atual, levados pela preferência dos técnicos ingleses, franceses e alemães que, pelos hábitos europeus, escolhiam o Mosqueiro para seus "week-end", a nossa gente seguiria seus passos, conquistando e descobrindo suas maravilhas.

O período de 1920 a 1960, na Amazônia, é marcado pela estagnação econômica resultante do fim da economia da borracha. No caso particular de Belém, os efeitos são bastante complexos. Apesar da crise econômica fortemente sentida também na cidade, a sua condição de "cabeça de rede", ou seja, de cidade primaz no âmbito da rede urbana ainda com características dendrítica, fez com que houvesse em Belém um forte crescimento populacional, alimentado pelos deslocamentos das áreas interioranas atreladas à extração do látex.

Desse modo, durante esse período de estagnação econômica regional, as características metropolitanas de Belém vão se tornando cada vez mais evidentes, especialmente, quando se consideram as mazelas sociais como componentes do cenário metropolitano. Nesse sentido, 
Trindade Júnior (1998) destaca entre os elementos da configuração urbana de Belém entre 1920 e 1960: a consolidação das atividades industriais nos bairros do Reduto e Comércio; o embrião de verticalização da área central; investimentos urbanos direcionados para os bairros de Nazaré e do Comércio; início da ocupação sistemática das baixadas ${ }^{3}$; criação de vilas e passagens nas áreas altas por setores de classe média. Todos esses importantes partícipes do processo de metropolização de Belém.

A partir dos anos 1960, a condição de Belém enquanto metrópole vai se afirmando cada vez mais, num primeiro momento, mantendo a forma denominada por Trindade Júnior (1998, p.104) de "confinada" e, mais tarde, a partir dos anos 1970, assumindo uma forma "dispersa", como exposto a seguir:

[As] áreas [institucionais], que passaram a formar uma espécie de cinturão em torno da parte mais densamente construída da cidade, obstacularizaram a expansão horizontal contínua, ao mesmo tempo em que aceleraram o adensamento populacional e a valorização dos terrenos de níveis mais altos, dentro da Primeira Légua da cidade.

A partir de então a cidade se densificou em vários setores, estabelecendo novas possibilidades de aproveitamento do espaço, com alternativas criadas pela população para a sua instalação. Foram ocupados, por exemplo, os núcleos dos grandes quarteirões com a abertura de vilas e passagens, ocuparam-se os terrenos de cotas mais baixas (as baixadas) e só depois ultrapassou-se, efetivamente, o chamado "cinturão institucional".

Com a ultrapassagem do "cinturão institucional", a partir da década de setenta, a malha urbana se expandiu para localidades até então consideradas distantes, notadamente para a Rodovia Augusto Montenegro (eixo Belém-Icoaraci) e para a BR-316 e Estrada do Coqueiro (eixo Belém-Ananindeua), ou seja, para além dos bairros integrantes da Primeira Légua ou daqueles adjacentes a esta.

Assim, a primeira forma de caráter metropolitano assumida por Belém caracteriza-se pelo uso intensivo do solo em um espaço razoavelmente restrito, a Primeira Légua Patrimonial, basicamente explicado pela existência do cinturão institucional, bem como pela inexistência de transporte coletivo urbano para além desse. Uma primeira versão do processo de verticalização, a ocupação do meio dos quarteirões e das baixadas derivam dessa situação. Nesse momento, cuja década de 1960 é a grande expressão, o processo de metropolização e sua forma espacial, a metrópole, estão bem definidos na densidade, diversidade e complexidade da dinâmica socioespacial de Belém, assim como na força e na amplitude dos seus papéis regionais, configurando uma área de influência cujos limites extrapolam o Estado do Pará. Referindo-se a Belém, nesse contexto da década de 1960, Moreira (1966) corrobora esse quadro ao sustentar que "na qualidade de centro metropolitano, ela se destaca sobretudo como sede político-administrativa, militar e econômica" (p.164).

Em termos socioespaciais, as desigualdades, que acompanham a estruturação da cidade desde muito cedo, atingiam, nos 1960, uma escala compatível com o papel de metrópole desempenhado por Belém, como ilustra bem a análise de Penteado (1968, p.197)

Em 1960, os bairros da zona norte e da zona sul continham a maior parte dos habitantes de Belém (cerca de 280.000 pessoas), em detrimento dos bairros do Centro e do Leste da cidade, o que se explica por serem aqueles bairros habitados por uma população muito pobre e bastante prolífera, que reside em pequenas casas ou em "barracas", construídas em lotes diminutos, às vezes mesmo, sobre as margens lodosas de igarapés, ao passo que a área central se vai esvaziando, graças a invasão do comércio, e os bairros da zona leste se estabilizam na tranquilidade de seus amplos quarteirões, separados pelas largas avenidas muito arborizadas.

A partir dos anos 1970, um processo de reestruturação da metrópole de Belém começou a ganhar forma e tinha na dispersão dos espaços de moradia o seu principal vetor. Foram fundamentais nesse processo de dispersão a constituição dos conjuntos habitacionais oriundos da atuação da Companhia de Habitação do Estado do Pará - COHAB, que se inseria em política mais ampla associada ao então

\footnotetext{
3 Termo utilizado em trabalhos acadêmicos, como em Trindade Júnior (1998), mas também pela população local em geral para se referir às adjacências de rios e igarapés que cortam a cidade de Belém, normalmente, densamente ocupadas e com topografias rebaixadas, facilitando, assim, a ocorrência de inundações. Em alguns casos, como na Avenida Visconde de Souza Franco, essas áreas, historicamente ocupadas pela população pobre, passaram por um processo de valorização imobiliária, que resultou no deslocamento da população preexistente e na chegada de grupos de renda mais elevada.
}

Caminhos de Geografia $\quad$ Uberlândia-MG $\quad$ v. 22, n. $80 \quad$ abr./2021 $\quad$ p. 97-118 Página 105


Banco Nacional de Habitação. O complexo Cidade Nova, em Ananindeua, é uma das grandes expressões desse processo, mas diversas áreas, especialmente no eixo da Avenida Augusto Montenegro e da BR-316, compõe o mesmo quadro.

Em termos socioespaciais, o processo de dispersão resultou na ampliação das desigualdades, já que foram basicamente grupos de baixa renda que compuseram esse movimento de saída dos espaços centrais, principalmente das baixadas, e de chegada no espaço metropolitano advindos da área de influência de Belém, configurando, desse modo, grandes espaços periféricos com infraestrutura precária e habitados por grupos de baixa renda, enquanto os espaços centrais registravam melhores condições de infraestrutura e eram ocupados por grupos de maior poder aquisitivo. Esse cenário foi reforçado pelo amplo surgimento de ocupações precárias nos arredores dos conjuntos habitacionais recém constituídos, viabilizadas pelo transporte coletivo urbano que passou a interligar os conjuntos habitacionais com a área central de Belém.

Com isso, Belém reafirmou sua condição metropolitana, ao ampliar seu contingente populacional, espraiar sua ocupação, fortalecer sua articulação com os municípios próximos, ampliar a escala dos movimentos pendulares, bem como também ratificar sua complexidade e desigualdade socioespaciais a partir da concentração de boa parte da população empobrecida do espaço metropolitano nas áreas distantes, onde basicamente se habitava, já que os empregos se mantinham concentrados no núcleo da metrópole.

\section{BELÉM: DE METRÓPOLE À CIDADE-REGIÃO}

Até os anos 1990, apenas alguns condomínios horizontais de alto padrão já estavam presentes nas áreas dispersas do espaço metropolitano de Belém e distantes do núcleo da metrópole, prevalecendo amplamente a condição de periferia desses espaços distantes, a partir de assentamentos resultantes da ação do Estado (conjuntos habitacionais), da atuação dos grupos sociais precariamente incluídos ${ }^{4}$ (ocupações precárias) e da operação de promotores imobiliários privados (residenciais de baixa renda).

Entretanto, passadas duas décadas, essa realidade ganhou novos delineamentos, isto é, apesar do processo de dispersão urbana continuar sendo marcante na dinâmica socioespacial de Belém, existem diferenças substanciais em relação ao que se verificava nos anos 1980 e 1990, condizente com a metropolização do espaço. E os novos fatores, ou atuais contornos de elementos preexistentes, segundo a análise aqui desenvolvida, não são mais passíveis de análise pela via da metropolização do espaço, já que resultam de processo mais amplo e multifacetado, a urbanização regional policêntrica e a materialização da forma urbana de cidade-região. Esses novos elementos, pontuados a partir daqui, com base nos dados obtidos a partir de levantamentos documentais e mediante trabalhos de campo, são o cerne da discussão desse tópico.

Antes de prosseguir, é conveniente antecipar, para facilitar a compreensão da discussão que se segue, a delimitação da cidade-região de Belém (figura 1), conforme estabelecido em Ribeiro (2017; 2018). Dois espaços distintos compõem a cidade-região de Belém, o espaço metropolitano, englobando Belém, Ananindeua, Marituba e Benevides, e o entorno metropolitano, abrangendo Barcarena, Santo Antônio do Tauá, Vigia, Santa Bárbara do Pará, Santa Izabel do Pará e Castanhal. O primeiro, mais denso, concentrado, complexo e com maior expressão do meio técnico-científicoinformacional, e o segundo, também complexo, porém, em comparação ao primeiro, menos denso, concentrado e com menor participação do novo meio geográfico associado à globalização.

\footnotetext{
${ }^{4}$ Expressão composta a partir da noção de grupos sociais excluídos, utilizada por Corrêa (1995) para se referir a coletivos de baixa renda que produzem espaços de assentamento caracterizados como favelas, como fruto de movimentos de ocupação e do emprego da autoconstrução na produção das habitações. Mesmo estando de acordo com o conteúdo da proposição de Corrêa, mediante a concordância com a noção de inclusão precária, presente em Martins (1997), e compreendendo que a atuação enquanto agente modelador do espaço é contraditória à condição de exclusão, pois pressupõe participação ativa, propõe-se o uso da expressão "grupos sociais precariamente incluídos", que associa a qualidade de agente à condição socioespacial de precariedade definidora do grupo em seu movimento de produção das ocupações precárias.

Caminhos de Geografia $\quad$ Uberlândia-MG $\quad$ v. 22, n. $80 \quad$ abr./2021 $\quad$ p. 97-118 Página 106
} 
Conforme sustentado em Ribeiro (2018, p.151),

[...] o reconhecimento dos dois subespaços componentes da cidade-região de Belém, o espaço metropolitano e o entorno metropolitano, tem validade do ponto de vista da diferenciação de áreas, da coesão espacial ou do princípio da homogeneidade, sempre relativa, do espaço. Entretanto, esse ainda não é o principal fator diferenciador para a presente abordagem, que privilegia o caráter relacional do espaço e, portanto, as interações espaciais como expressão dessa natureza do espaço. E por esse critério, as diferenças entre esses dois subespaços reconhecidos no interior da cidade-região de Belém ficam ainda mais evidentes [...].

Figura 1 - Cidade-Região de Belém. Municípios componentes. 2016.

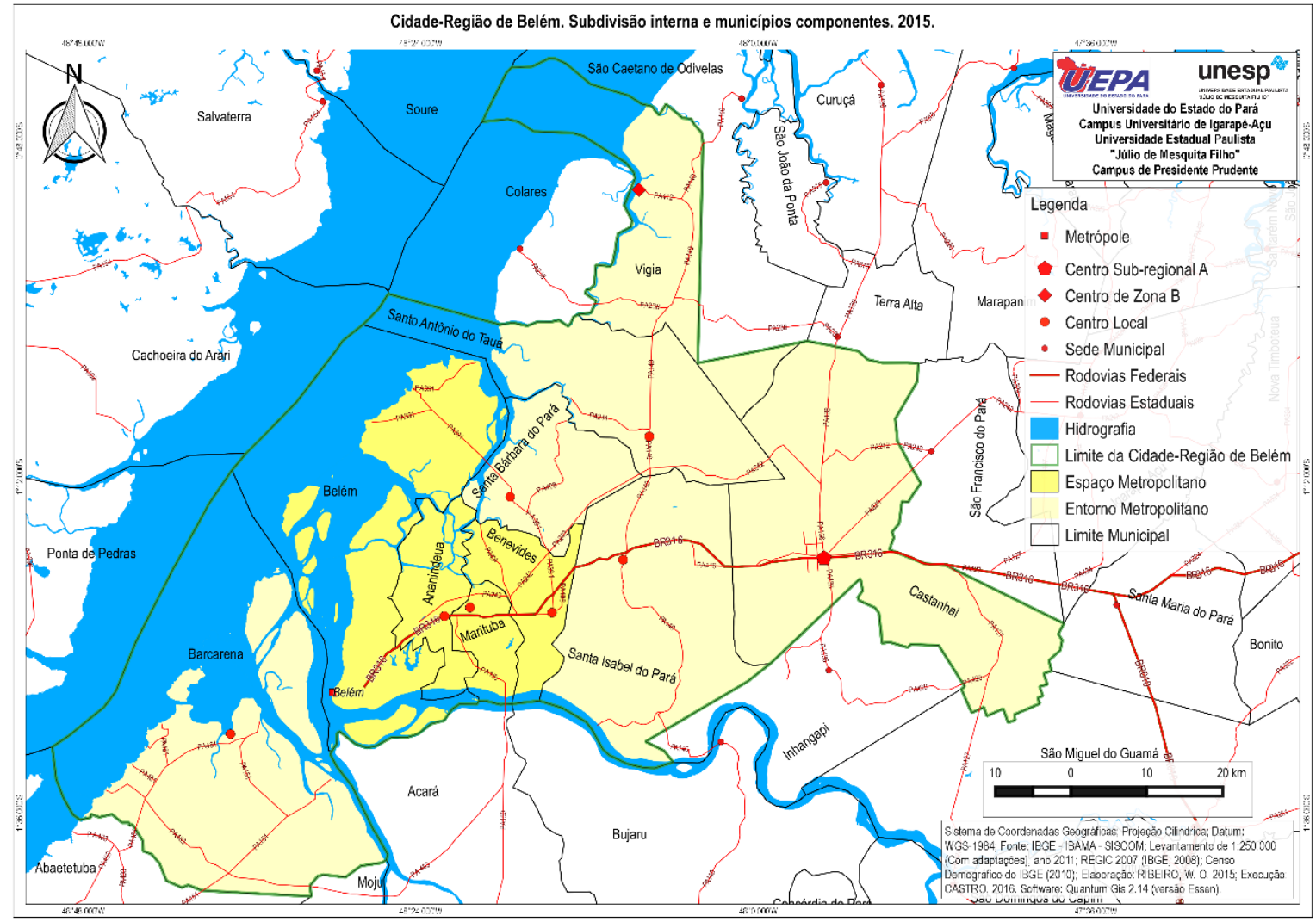

Fonte - Ribeiro (2017).

Assim, a delimitação da cidade-região de Belém tomou por base a compreensão do espaço de um ponto de vista relacional, considerando tanto sua materialidade, a partir das características dos sistemas de objetos, quanto às suas articulações, mediante a análise das interações espaciais. $\mathrm{Na}$ análise dos fatores que qualificam o processo de urbanização regional policêntrica e a forma cidaderegião, que compõem os pontos subsequentes, mantém-se o mesmo perfil de análise.

\section{Diversidade de renda e de tipos de assentamentos dos grupos sociais nas antigas e novas áreas dispersas}

De forma alguma, os conjuntos habitacionais, as ocupações precárias e os residenciais de baixa renda, basilares no movimento de dispersão urbana evidenciado em Belém até os anos 1990, desapareceram ou deixaram de ser relevantes no espaço metropolitano além do seu núcleo, todavia, hoje, somam-se a uma diversidade de outros espaços de assentamento e de grupos a eles correlacionados.

Considerando os espaços além da primeira légua patrimonial de Belém, o que inclui muitas áreas antes descontínuas ao núcleo metropolitano e atualmente contíguas, como é o caso do eixo da

Caminhos de Geografia $\quad$ Uberlândia-MG $\quad$ v. 22, n. $80 \quad$ abr./2021 $\quad$ p. 97-118 Página 107


Avenida Augusto Montenegro, e áreas mais recentes, distantes e descontínuas ao núcleo metropolitano; evidencia-se um aprofundamento da diversificação dos tipos de assentamentos, acompanhando as elevadas disparidades de renda, e, por conseguinte, das desigualdades socioespaciais internas a esses espaços, ao passo em que se veem reduzidas as diferenciações, considerando a realidade anterior, com relação à primeira légua.

Espaços atualmente contíguos ao núcleo metropolitano, como o eixo da Avenida Augusto Montenegro e o eixo da BR-316, especialmente até o limite do município de Ananindeua, passaram por forte diversificação, isto é, somaram às ocupações precárias, aos antigos conjuntos habitacionais e aos antigos residenciais de baixa renda, razoável quantidade e diversidade de condomínios fechados horizontais e verticais voltados a grupos de média e alta renda.

Com relação aos espaços fechados de média renda verticalizados, especial destaque cabe às políticas do Programa Minha Casa Minha Vida (PMCMV), do Governo Federal, que por meio de suas faixas 2 e 3 produziram grande número de empreendimentos nesses espaços além da primeira légua de Belém, indo, inclusive, adiante dos limites de Ananindeua, atingindo fortemente o município de Marituba (figura 2), por exemplo. Acompanhando, prioritariamente, os principais eixos de circulação como BR-316, Avenida Augusto Montenegro, Avenida Mário Covas e Avenida Governador Hélio Gueiros.

Figura 2 - Marituba. Empreendimentos imobiliários privados e do PMCMV. 2017.

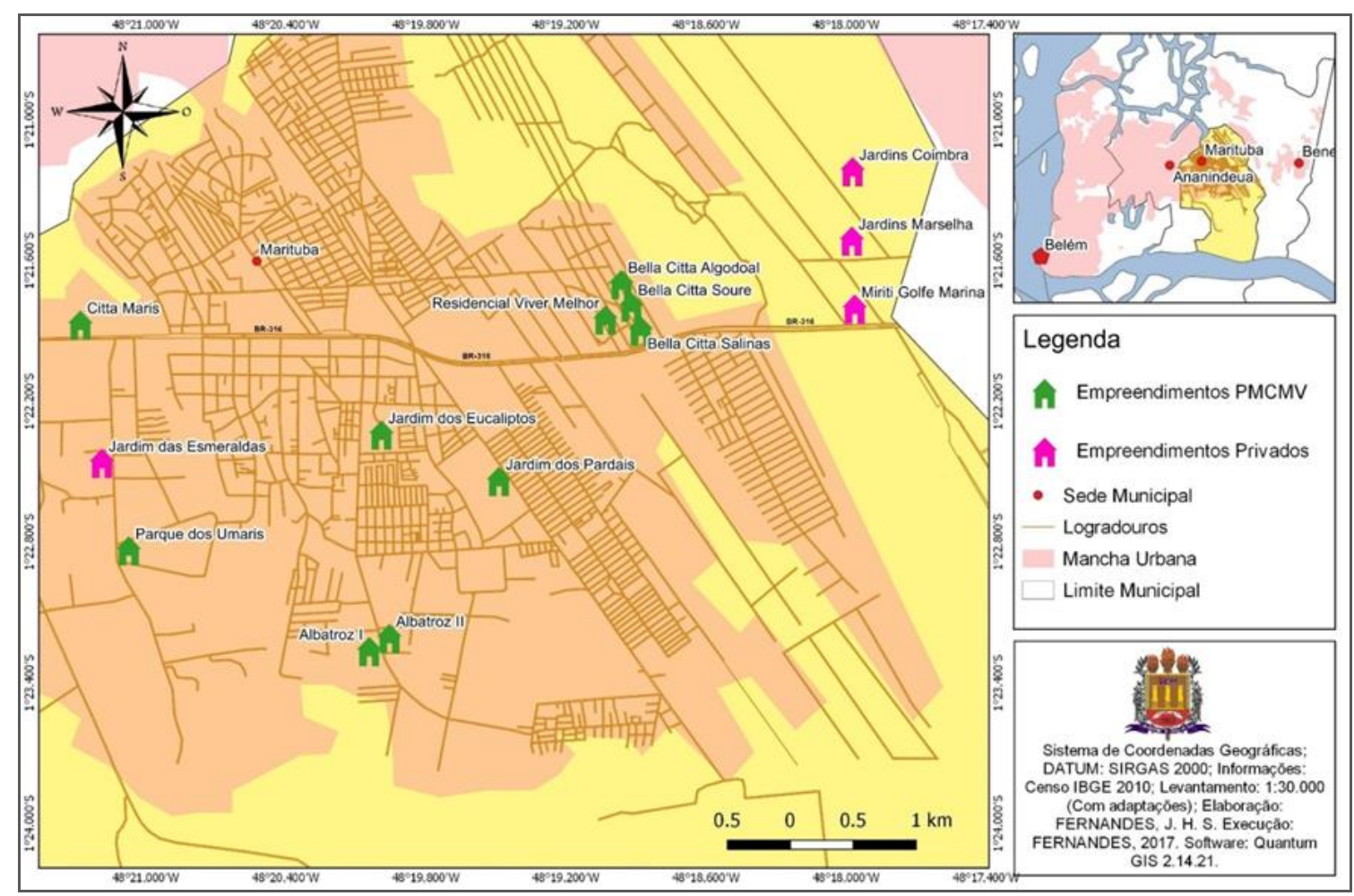

Fonte - Fernandes e Ribeiro (2019).

No tocante às áreas com algum nível de descontinuidade quanto ao núcleo metropolitano, a exemplo de espaços em Marituba e Benevides, porém componentes do espaço metropolitano de Belém, esse processo de diversificação também se apresenta de forma relevante, com a produção de condomínios horizontais de alto padrão em espaços muito distantes, condomínios de médio padrão ligados ao PMCMV, novos residenciais abertos resultantes da faixa 1 do PMCMV, bem como o surgimento de novas ocupações precárias. À exceção da última modalidade de assentamento, a figura 2 representa essa diversidade em Marituba.

Já no entorno metropolitano, cabe destaque, no aspecto em questão, à Castanhal, que, mesmo não possuindo sua ocupação advinda da dispersão de população pobre a partir de Belém, mediante uma dinâmica mais autônoma, mantinha as áreas mais afastadas do centro com características quase que

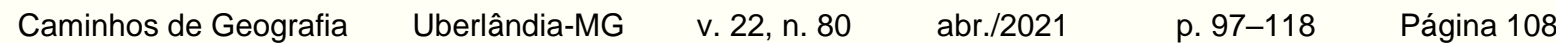


exclusivamente de periferia urbana, diferentemente do quadro atual, no âmbito da sua participação na cidade-região de Belém, quando ocorre uma razoável diversificação desses espaços, como fica evidente no estudo de Santos (2019), especialmente na representação condizente com a figura 3.

Figura 3 - Castanhal. Diversidade dos assentamentos urbanos recentes. 2019.

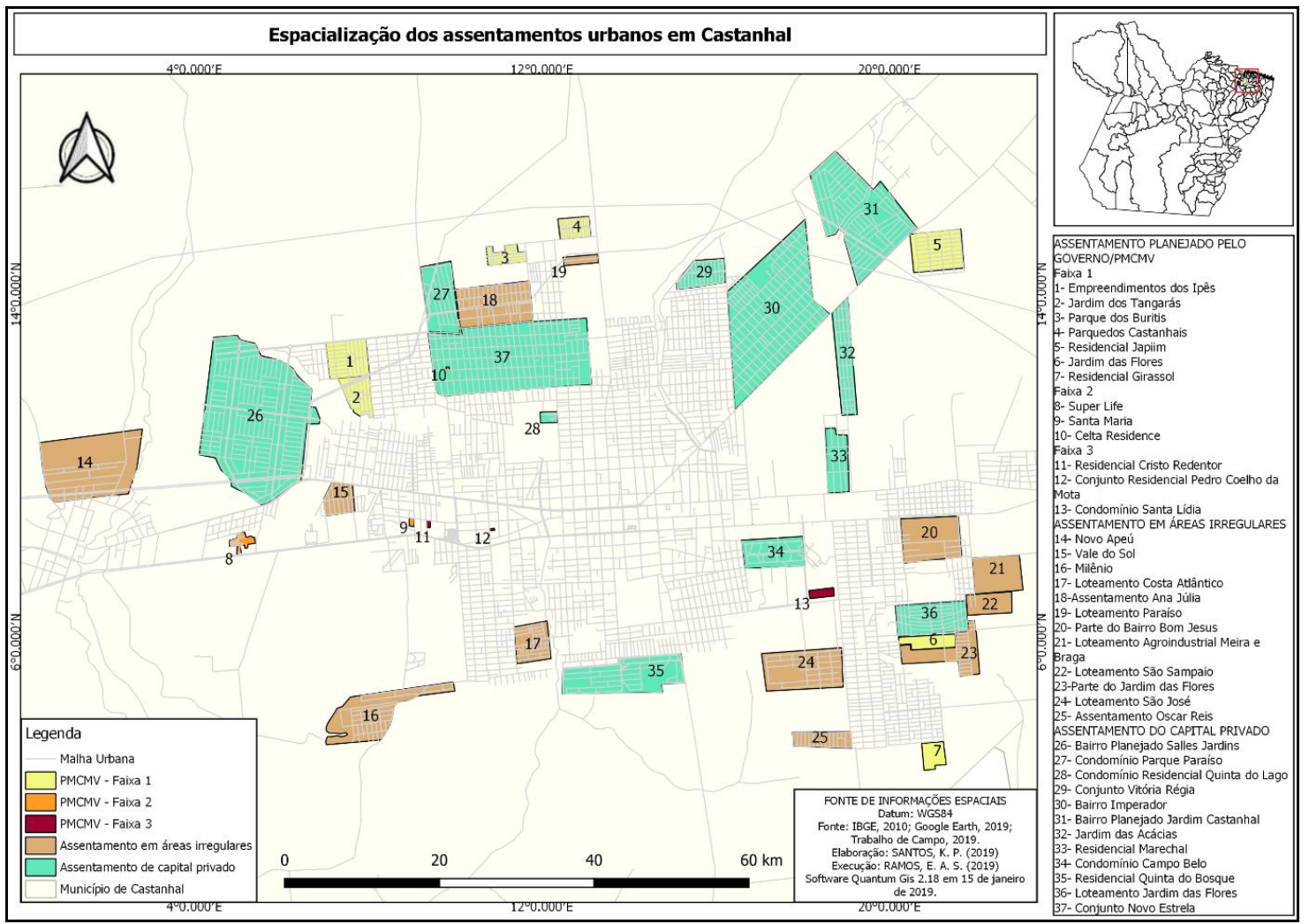

Fonte - Santos (2019).

A expansão urbana de Castanhal, nas últimas duas décadas, rompeu com o predomínio das ocupações precárias e passou a contar com a substancial importância dos empreendimentos ligados ao Programa Minha Casa Minha Vida e também com ações de promotores imobiliários privados, seja na produção de loteamentos ou de condomínios fechados de médio e alto padrão. Nesses termos, seguindo a mesma lógica manifesta no espaço metropolitano.

\section{Dispersão dos espaços de consumo}

Acompanhando o adensamento populacional e a diversificação dos tipos de assentamento, bem como da renda das famílias, houve uma significativa expansão das atividades de comércio e serviços para as áreas situadas além da primeira légua patrimonial de Belém. No caso do espaço metropolitano, essa expansão é mais significativa em áreas pertencentes ao município de Belém e de Ananindeua. Ao levar-se em conta o entorno metropolitano, percebe-se a manifestação de dinâmica semelhante em Castanhal.

Desse modo, considerando as principais redes de comércio varejista locais (Líder, Formosa e Nazaré), fortemente identificadas com o núcleo metropolitano e com atuação a partir de supermercados e magazines, entre outros serviços, todas atuam também em áreas externas à primeira légua de Belém. Nesse sentido, realça-se a atuação do Grupo Líder que dispõe de seis lojas em Belém além de sua primeira légua; uma loja em Ananindeua; duas em Castanhal (a terceira está em construção) e uma loja em Barcarena.

O Meio a Meio Preço Baixo, rede local com importância mais recente, até há pouco tempo, possuía atuação apenas externa à Primeira Légua Patrimonial de Belém. Da mesma forma, grandes redes de comércio nacionais e internacionais, recentemente instaladas no espaço metropolitano de Belém, a

Caminhos de Geografia $\quad$ Uberlândia-MG $\quad$ v. 22, n. $80 \quad$ abr./2021 $\quad$ p. 97-118 Página 109


exemplo do Assaí Atacadista (loja na Avenida Mário Covas, em Belém, limite com Ananindeua, loja em Ananindeua e em Castanhal) e do Atacadão Carrefour (uma loja em Icoaraci/Belém, duas em Ananindeua e uma em Castanhal) estão exclusivamente além dos limites na primeira légua. Situação parecida com o Grupo Mateus, que, em Belém, das três lojas duas estão adiante da primeira légua patrimonial de Belém, dispondo ainda de duas lojas em Ananindeua, uma em Marituba e duas em Castanhal.

O panorama das estratégias locacionais desses grupos demonstra tanto a densidade da oferta dispersa de comércio e serviços no âmbito do espaço metropolitano, quanto a relevância de Castanhal enquanto segundo espaço central da cidade-região. No mesmo sentido estão os Shoppings Centers, dos seis principais do espaço metropolitano de Belém, apenas dois estão na área central de Belém, porém, sem possuir correspondência em Castanhal, que não dispõe de nenhum empreendimento do tipo em funcionamento, apenas em construção.

\section{Ampliação da escala da dispersão e novas periferias}

A configuração da metrópole de Belém enquanto cidade dispersa, conforme reconhecido em Trindade Júnior (1998), dá-se por um processo de dispersão urbana, entre os anos 1970 e 1990, fortemente caracterizado pelo deslocamento de assentamentos de grupos de baixa renda, em conformidade com o já discutido. Nas décadas mais recentes, como também já apresentado, os espaços originários dessa dinâmica passaram por relevantes modificações no sentido da diversificação dos tipos de assentamento, do padrão de renda dos moradores, bem como pelo adensamento e qualificação das atividades de comércio e serviço.

Entretanto, essa realidade não implica na constatação do desfecho do processo de dispersão da pobreza, pelo contrário, na atualidade, ainda continuam se reproduzindo espaços majoritariamente compostos por assentamentos precários, mesmo que tenham origem na ação de variados agentes, contudo, diferentemente do período anterior, em áreas muito distantes da área central de Belém, ou mesmo em áreas cuja referência de espaço central mais relevante não é Belém, tal qual o caso dos novos espaços precários produzidos em Castanhal, especialmente, aqueles descontínuos ao seu tecido urbano.

Em se tratando especificamente do espaço metropolitano de Belém, se boa parte da área passa por um movimento de diversificação, modernização e complexificação, em contrapartida, existem espaços que estão cada vez mais se distinguindo pela reunião de assentamentos precários. Este é o caso do distrito de Mosqueiro, tradicional espaço de lazer, especialmente por suas praias, desde o final do século XIX. Até o final do século XX, Mosqueiro manteve-se usufruída, principalmente, por setores abastados de Belém, quando, então, passou a ser intensamente frequentada por grupos de baixa renda, pejorativamente nomeados de "farofeiros", num processo marcado por conflitos associados à luta de classes e com reverberação no plano territorial, como analisado por Ribeiro (2007, 2014).

Acompanhando essa metamorfose no uso das praias do arquipélago de Mosqueiro, observa-se também transmutações em outras esferas da vida social, sempre acompanhadas da precarização, como no caso dos transportes, dos serviços básicos e infraestruturas e, naquilo que mais importa aqui, da habitação e moradia, com a reprodução de loteamentos privados, de empreendimentos da faixa 1 do PMCMV e ocupações, todos claramente marcados pela precariedade, potencializada pelas grandes distâncias em relação a serviços fundamentais.

Exemplificando essas condições, o Residencial Viver Mosqueiro expõe as características de precarização normalmente associadas aos empreendimentos da faixa 1 do PMCMV, conforme atestado por inúmeros estudos no Brasil, cabendo destacar a baixa qualidade das habitações e o seu distanciamento em relação aos serviços públicos como saúde, educação e segurança.

Elementos correlatos podem ser identificados nas ocupações, cuja presença em Mosqueiro é bem mais disseminada, conforme expõe o estudo de Ferreira (2012) e fica evidente na quantidade de ocupações relacionadas no quadro 2, com a maior parte delas surgidas entre os anos de 2000 e 2008, levando Ferreira (2012, p.117) a constatar que Mosqueiro, um distrito até outrora estimado por seu papel enquanto espaço de lazer suburbano, "vem se conformando como um novo espaço de assentamentos residenciais precários, onde se percebe, por conta disto, o aumento da concentração de pobreza em seu território". 
No tocante ao entorno metropolitano, esse processo de ampliação da escala da dispersão dos assentamentos precários também se faz notar, com destaque, mais uma vez, à cidade de Castanhal, que, conforme ocorreu no espaço metropolitano, passou por um processo de complexificação e diversificação de seus espaços até então periféricos. Com isso, as bordas da cidade, antes quase que exclusivamente compostas por ocupações, loteamentos privados e conjuntos habitacionais, todos de natureza precária, passaram a contar com outras modalidades de assentamentos, como os condomínios fechados de médio e alto padrão e loteamentos privados voltados a grupos de média renda, diminuindo sensivelmente os espaços contíguos à cidade e passíveis de serem utilizados em novas ocupações. ${ }^{5}$

Quadro 2 - Distrito de Mosqueiro/Belém. Ocupações e seus respectivos bairros. 2008.

\begin{tabular}{|c|c|c|c|c|c|}
\hline & Ocupação & $\begin{array}{c}\text { Bairro de } \\
\text { localização }\end{array}$ & & Ocupação & $\begin{array}{l}\text { Bairro de } \\
\text { localização }\end{array}$ \\
\hline 01 & Pantanal & Vila & 17 & Pução & Carananduba \\
\hline 02 & Cajueirinho & Maracajá & 18 & Curvão & Carananduba \\
\hline 03 & Poeirão & Praia Grande & 29 & Bairro Novo & Carananduba \\
\hline 04 & Fazenda Clube & Praia Grande & 20 & Lote do Mendes & Carananduba \\
\hline 05 & Jardim Rosália & Chapéu Virado & 21 & Estrela da Manhã & Carananduba \\
\hline 06 & Prainha & Prainha & 22 & Coréia & Carananduba \\
\hline 07 & Murubira & Murubira & 23 & Taba (Mártires de Abril) & Carananduba \\
\hline 08 & ASCB & Natal do Murubira & 24 & Caruara & Caruara \\
\hline 09 & Consciência & Porto Arthur & 25 & Vale do Paraíso & Paraíso \\
\hline 10 & Variante & Murubira & \multirow{2}{*}{26} & \multirow{2}{*}{$\begin{array}{l}\text { Associação dos Produtores } \\
\text { Rurais da Ocupação Arlinda } \\
\text { Gomes do Vale (APROAR) }\end{array}$} & \multirow{2}{*}{ Sucurijuquara } \\
\hline 11 & Vasco da Gama & Murubira & & & \\
\hline 12 & Ariramba (Coragem) & Ariramba & 27 & Ipixuna & Baía do Sol \\
\hline 13 & Terra Alta & $\begin{array}{c}\text { Bonfim/São } \\
\text { Francisco }\end{array}$ & 28 & São Geraldo & Baía do Sol \\
\hline 14 & Igaracoco & São Francisco & 29 & Parque Severino & Baía do Sol \\
\hline 15 & Cajueiro (Vila Sapo) & Carananduba & 30 & Dorothy I & PA-391 \\
\hline 16 & Vila de pescadores & Carananduba & 31 & Dorothy II & Rod. BL-13 \\
\hline
\end{tabular}

Não obstante, o resultado desse processo não foi a eliminação das ocupações precárias em Castanhal, mas sim a alteração da lógica da expansão urbana de contígua para descontínua, num movimento de dispersão urbana que atinge espaços para além do perímetro urbano, tradicionalmente rurais, especialmente aqueles condizentes com algumas agrovilas, ou em seus arredores, como Calúcia, a nordeste da sede municipal, e Castelo Branco, a sudeste da cidade ${ }^{6}$.

\footnotetext{
${ }^{5}$ Resultados obtidos a partir dos projetos, coordenados pelo autor e vinculados ao Grupo de Pesquisa Geografia do Pará Urbano - GeoPUrb, "Expansão do espaço urbano e habitação na cidade média de Castanhal/Pará: áreas de ocupação e empreendimentos da Faixa 1 do PMCMV" (desenvolvido entre 2017 e 2018, no âmbito da Universidade do Estado do Pará e com financiamento da Fundação Amazônia de Amparo a Estudos e Pesquisas do Pará - FAPESPA) e "Dinâmica imobiliária e expansão do espaço urbano na cidade média de Castanhal/Pará: Programa Minha Casa Minha Vida e loteamentos privados no eixo da PA-320" (desenvolvido entre 2018 e 2019 , no quadro da Universidade do Estado do Pará e com financiamento do Conselho Nacional de Desenvolvimento Científico e Tecnológico - CNPq).

${ }^{6}$ Resultados obtidos a partir do projeto, também coordenado pelo autor e inserido no GeoPUrb, "Marginalizados e invisíveis em margens e confins: a produção do espaço urbano de Castanhal e a dinâmica socioespacial das
}

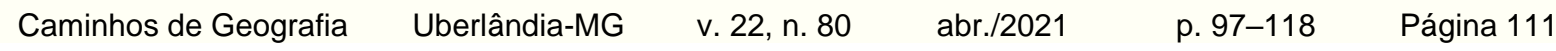


A configuração dessas agrovilas em espaços com características urbanas e com cotidiano cada vez mais vinculado à sede municipal (o que se faz sentir nos movimentos pendulares, tipos de empregos, hábitos de consumo, modos de vida, atividades econômicas etc.) representa um alargamento do tecido urbano, bem como a reprodução da precariedade, agora invisível à maior parte da população por sua remota localização.

\section{Fortalecimento de outras centralidades e diversificação dos sentidos dos fluxos}

Um dos atributos da condição metropolitana de Belém até os anos 1990 era a configuração de seu núcleo como concentrador quase absoluto da atividade comercial e de serviços, bem como da grande maioria da atividade econômica e da geração de empregos, dando concretude, nesses moldes, a um espaço metropolitano com fluxos unidirecionais, facilmente percebidos no intenso movimento de entrada na área central, no início da manhã, e de saída, no fim de tarde, nas vias rodoviárias principais de articulação entre as áreas dispersas e o núcleo da metrópole, assim como na baixa frequência do trânsito no sentido oposto. Até esse momento, as dinâmicas de caráter metropolitano restringiam-se aos municípios de Belém, Ananindeua, Marituba e Benevides.

As duas últimas décadas testemunharam mudanças significativas nesse quadro por meio da intensificação dos fluxos e, principalmente, da diversificação de suas direções, percebendo-se, com isso, fluxos intensos de saída e de entrada no núcleo metropolitano tanto no início de manhã quanto no final de tarde. E esse novo perfil relaciona-se diretamente ao fortalecimento de espaços centrais além da primeira légua patrimonial de Belém, sejam eles integrantes do espaço metropolitano ou do entorno metropolitano.

Atrelados a já discutida dispersão dos espaços de consumo, no âmbito do espaço metropolitano, as últimas décadas presenciaram a consolidação de diversos espaços centrais externos à primeira légua, sejam eles em forma de eixo ou área, cabendo destacar:

- Áreas centrais de Ananindeua, Marituba e Benevides, todas no eixo da BR-316, as duas primeiras às suas bordas, inclusive;

- Entroncamento, ainda no território municipal de Belém, estendendo-se ao Shopping Castanheira e seu entorno;

- Eixo da Avenida Augusto Montenegro, dotado de shopping center e das principais redes de comércio varejista com atuação no espaço metropolitano;

- Icoaraci, antigo espaço descontínuo e agora componente de extensa e dinâmica área de intensa produção do espaço, juntamente com as Avenidas Augusto Montenegro e Arthur Bernardes, a partir dos setores industrial, imobiliário e de comércio e serviços;

- Cidade Nova, integrante do município de Ananindeua e conformando-se como um complexo de conjuntos habitacionais, entre as décadas de 1970 e 1980, a partir das políticas associadas ao Banco Nacional de Habitação - BNH, constituindo-se enquanto um centro de comércio e serviços para uma extensa área, a partir de diversos eixos viários e áreas de concentração de comércio e serviços.

Esses espaços centrais destacam-se por sua centralidade relativa ao setor de comércio e serviços, desempenhando o papel de subcentros do espaço metropolitano, ou seja, oferecem seus serviços a setores desse espaço que congregam vários bairros. Dispõem de serviços diversificados e com razoável nível de complexidade, incluindo supermercados e lojas de departamentos de grandes redes, agências bancárias, serviços de saúde, entre outros. Nenhum deles atinge complexidade suficiente para questionar a condição do centro principal de Belém enquanto tal, entretanto, representam uma dispersão de serviços antes muito concentrados na área central de Belém e geram grande diversificação dos sentidos dos fluxos, bem como atuam na valorização de localizações antes pouco prestigiadas, revelando a sua conexão com outro setor econômico de forte implicação na produção da cidade-região de Belém, a promoção imobiliária.

Apesar de diversos agentes estarem envolvidos no processo (como o próprio Estado, que tem papel determinante), não se pode desconsiderar a relevância das ações do capital imobiliário na produção e

ocupações precárias", em execução, desde 2019, no âmbito da Universidade do Estado do Pará e com financiamento do Conselho Nacional de Desenvolvimento Científico e Tecnológico - CNPq.

Caminhos de Geografia $\quad$ Uberlândia-MG $\quad$ v. 22, n. $80 \quad$ abr./2021 $\quad$ p. 97-118 Página 112


qualificação desses subcentros, seja por meio da sua atuação na dispersão dos grupos de média e alta renda, com a construção dos condomínios fechados, por exemplo, mas também na produção de grandes superfícies comerciais que potencializam ou geram novas centralidades. Um exemplo dessa ocorrência é o Parque Shopping, localizado no subcentro em eixo da Avenida Augusto Montenegro, produzido pelo Grupo Status Construções, que também foi responsável pela produção do complexo de condomínios Chácaras Montenegro, associado ao shopping, assim como o prédio empresarial Parque Office, ocupante do mesmo terreno que o Parque Shopping.

Com relação ao entorno metropolitano, os espaços centrais cumprem papel distinto, associado à própria natureza desse conjunto, assim, se no espaço metropolitano a condição de subcentro dos espaços centrais anteriormente citados é bastante evidente, o mesmo não se pode dizer do entorno metropolitano, cuja articulação com Belém ainda é melhor interpretada pela via interurbana que pela perspectiva intraurbana, o que remete a uma das complexidades inerentes à cidade-região, a articulação e, ao mesmo tempo, certa indefinição da escala.

Nesse contexto, os espaços centrais das cidades que compõem o entorno metropolitano exercem importantes, apesar de bastante heterogêneos, níveis de centralidade no âmbito da cidade-região de Belém. A maior parte delas (Santa Izabel do Pará, Santo Antônio do Tauá, Vigia e Castanhal) possui estrutura urbana definida a partir de um único centro aglutinador, principalmente, das atividades de comércio e serviços, o que em alguns casos, como o de Castanhal, funciona como um trunfo na facilitação dos papéis regionais. Santa Bárbara do Pará possui a particularidade de ser dotada de duas áreas, apesar de próximas, com concentração de atividades de comércio e serviços, o centro principal e Pau D'arco. Numa envergadura bem maior, duas áreas centrais também são verificadas em Barcarena: Centro e Vila dos Cabanos. A última com origem numa company town ligada à produção de alumínio, que responde por uma segunda particularidade de Barcarena, o único município da cidade-região de Belém a ter a indústria como principal setor econômico. (Tabela 1)

Tabela 1 - Cidade-Região de Belém. Produto Interno Bruto dos Municípios. 2000 e 2017.

\begin{tabular}{|c|c|c|c|c|c|c|c|}
\hline \multicolumn{2}{|c|}{ Municípios } & \multicolumn{2}{|c|}{$\begin{array}{c}\text { Valor adicionado bruto } \\
\text { da INDÚSTRIA (x } \\
\text { 1000) R\$ }\end{array}$} & \multicolumn{2}{|c|}{$\begin{array}{c}\text { Valor adicionado bruto } \\
\text { dos SERVIÇOS (x } \\
\text { 1000) R\$ }\end{array}$} & \multicolumn{2}{|c|}{$\begin{array}{c}\text { PIB a preços correntes } \\
\qquad(\text { (x 1000) } \mathrm{R} \$\end{array}$} \\
\hline & & 2000 & 2017 & 2000 & 2017 & 2000 & 2017 \\
\hline \multirow{4}{*}{ 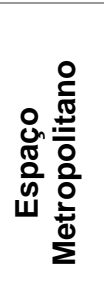 } & Belém & $912.775,00$ & $\begin{array}{c}3.658 .234,0 \\
3\end{array}$ & $\begin{array}{c}4.692 .473,0 \\
0\end{array}$ & $\begin{array}{c}17.155 .769,2 \\
7\end{array}$ & $\begin{array}{c}6.464 .402,0 \\
0\end{array}$ & $\begin{array}{c}30.238 .483,9 \\
6\end{array}$ \\
\hline & $\begin{array}{c}\text { Ananindeu } \\
\text { a }\end{array}$ & $185.404,00$ & $\begin{array}{c}1.099 .382,0 \\
7\end{array}$ & $648.637,00$ & $3.482 .314,38$ & $962.542,00$ & $6.979 .135,03$ \\
\hline & Marituba & $19.731,00$ & $148.231,81$ & $74.351,00$ & $907.907,43$ & $101.310,00$ & $1.787 .967,21$ \\
\hline & Benevides & $7.871,00$ & $409.696,87$ & $39.064,00$ & $501.371,19$ & $53.787,00$ & $1.393 .884,54$ \\
\hline \multirow{6}{*}{ 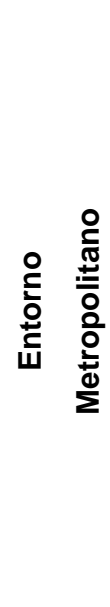 } & Barcarena & $\begin{array}{c}1.007 .833,0 \\
0\end{array}$ & $\begin{array}{c}2.001 .463,1 \\
7\end{array}$ & $307.697,00$ & $1.122 .268,62$ & $\begin{array}{c}1.491 .809,0 \\
0\end{array}$ & $4.815 .194,14$ \\
\hline & $\begin{array}{l}\text { Santa } \\
\text { Bárbara } \\
\text { do Pará }\end{array}$ & $4.553,00$ & $34.459,51$ & $10.802,00$ & $37.883,68$ & $20.160,00$ & $165.802,04$ \\
\hline & $\begin{array}{l}\text { Santa } \\
\text { Izabel do } \\
\text { Pará }\end{array}$ & $7.199,00$ & $80.693,55$ & $49.544,00$ & $242.925,48$ & $70.148,00$ & $718.727,37$ \\
\hline & $\begin{array}{l}\text { Santo } \\
\text { Antônio do } \\
\text { Tauá }\end{array}$ & $3.824,00$ & $30.583,08$ & $19.429,00$ & $65.797,65$ & $31.103,00$ & $343.978,54$ \\
\hline & Vigia & $3.892,00$ & $16.177,63$ & $35.510,00$ & $101.954,07$ & $48.778,00$ & $373.285,56$ \\
\hline & Castanhal & $62.059,00$ & $588.918,46$ & $230.323,00$ & $1.782 .470,51$ & $333.011,00$ & $3.757 .158,78$ \\
\hline
\end{tabular}


A tabela 1 expõe o Produto Interno Bruto dos municípios da Cidade-Região de Belém, tanto os do espaço metropolitano quanto do entorno metropolitano, bem como a produção nos setores industrial e de serviços. Nota-se que a quase totalidade dos municípios apresenta prevalência do setor de serviços e que Belém mantém com folga sua condição de núcleo da cidade-região, pelo aspecto em questão.

Outra observação relevante é que os demais componentes do espaço metropolitano se destacam no conjunto da cidade-região por seu PIB, mas com uma vantagem muito grande de Ananindeua, refletindo forte integração à Belém e os processos já descritos de dispersão de atividades de comércio e serviços, dinâmica imobiliária, etc. O entorno metropolitano apresenta grande diversidade em relação ao PIB, com alguns municípios pouco expressivos, e um destaque à Barcarena, especialmente devido à produção industrial, uma das grandes responsáveis pela própria importância dos serviços, especialmente associadas ao alumínio, na geração de demandas por serviços, por exemplo, a partir dos seus funcionários, explicando a configuração da centralidade em Vila dos Cabanos. O outro município de destaque no entorno metropolitano é Castanhal, que, apesar da razoável atividade industrial, tem nos serviços o seu principal setor econômico, condição frontalmente concatenada com o substancial papel regional exercido pela cidade.

Outra informação fundamental na tabela 1, e que se coaduna com o processo de urbanização regional policêntrica e sua forma espacial cidade-região, é o fato de que todos os municípios do conjunto, à exceção de Barcarena, têm crescimento do PIB superior à Belém, entre 2000 e 2017, alguns deles com vantagens muito expressivas, como Marituba e Benevides, no espaço metropolitano, e Castanhal, no entorno metropolitano. Esse dado expressa a configuração das diversas centralidades e a diminuição do distanciamento relativo entre o núcleo da cidade-região e seus demais componentes.

Com relação às interações espaciais, fundamentais à definição da natureza de cidade-região, bem como ao reconhecimento de sua abrangência, em Ribeiro (2017; 2018) foram utilizados os deslocamentos temporários de pessoas por motivo de trabalho e estudo, como definido nas obras, para verificar as intensidades das interações e, desse modo, reconhecer os municípios que compõem a cidade-região de Belém, como exposto na tabela 2 em relação aos deslocamentos por trabalho.

A tabela 2 expõe os municípios que compõem a cidade-região, que são, justamente, aqueles com maiores deslocamentos temporários por motivo de trabalho para Belém. Fica evidente a diferenciação de intensidades entre os municípios do espaço metropolitano e aqueles do entorno metropolitano, sendo essa realidade uma das bases do reconhecimento desses espaços enquanto distintos, contudo, sem anular a participação de ambos no conjunto maior, a cidade-região de Belém, entre outros fatores, pelas importantes articulações existentes.

Tabela 2 - Cidade-Região de Belém. Deslocamentos temporários de pessoas por motivo de trabalho com destino ao Município de Belém/PA. 2010.

\begin{tabular}{|c|c|c|c|c|}
\hline & $\begin{array}{l}\text { MUNICÍPIO DE } \\
\text { ORIGEM* }^{*}\end{array}$ & $\begin{array}{l}\text { QUANTIDADE DE } \\
\text { PESSOAS }\end{array}$ & $\begin{array}{l}\text { POPULAÇÃO DO } \\
\text { MUNICÍPIO DE } \\
\text { ORIGEM }\end{array}$ & IIDTT* \\
\hline \multirow{3}{*}{ 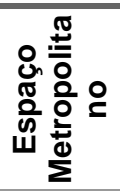 } & Ananindeua & 65621 & 471.980 & 139 \\
\hline & Marituba & 10879 & 108.246 & 101 \\
\hline & Benevides & 3827 & 51.651 & 74 \\
\hline \multirow{6}{*}{ 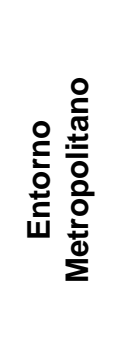 } & Santa Bárbara do Pará & 761 & 17.141 & 44 \\
\hline & Santo Antônio do Tauá & 596 & 26.674 & 22 \\
\hline & Santa Izabel do Pará & 1193 & 59.466 & 20 \\
\hline & Vigia & 396 & 47.889 & 8 \\
\hline & Castanhal & 1319 & 173.149 & 8 \\
\hline & Barcarena & 606 & 99.859 & 6 \\
\hline
\end{tabular}

*Índice de Intensidade do Deslocamento Temporário por Trabalho - alcançado a partir da divisão do número de pessoas que realizaram o deslocamento por trabalho pela população total do município de origem em 2010, multiplicado por 1000 .

Fonte - Ribeiro (2017).

Caminhos de Geografia $\quad$ Uberlândia-MG $\quad$ v. 22, n. $80 \quad$ abr./2021 $\quad$ p. 97-118 Página 114


Para encerrar o debate em torno das centralidades diversas da cidade-região de Belém, cabe um ressalto à Castanhal. Tomando por base o estudo "Regiões de Influência das Cidades - REGIC 2018 (IBGE, 2020), além da metrópole de Belém (que também abrange Ananindeua, Marituba e Benevides), apenas duas outras cidades não são classificadas como Centros Locais: Barcarena (Centro Sub-regional B) e Castanhal (Capital Regional C). A existência deles é indispensável ao reconhecimento da cidade-região, como exposto em Magalhães (2008), pois a sua dinâmica de centralidade rompe com o protagonismo quase absoluto de uma única cidade, associado ao padrão metropolitano, dando concretude a uma nova realidade que contém e ultrapassa a metrópole e sua região, marcada por centros urbanos com centralidades regionais próprias (figura 4), porém inseridos num espaço relacional comum, a cidade-região.

Figura 4 - Castanhal. Região imediata de articulação urbana. 2013.

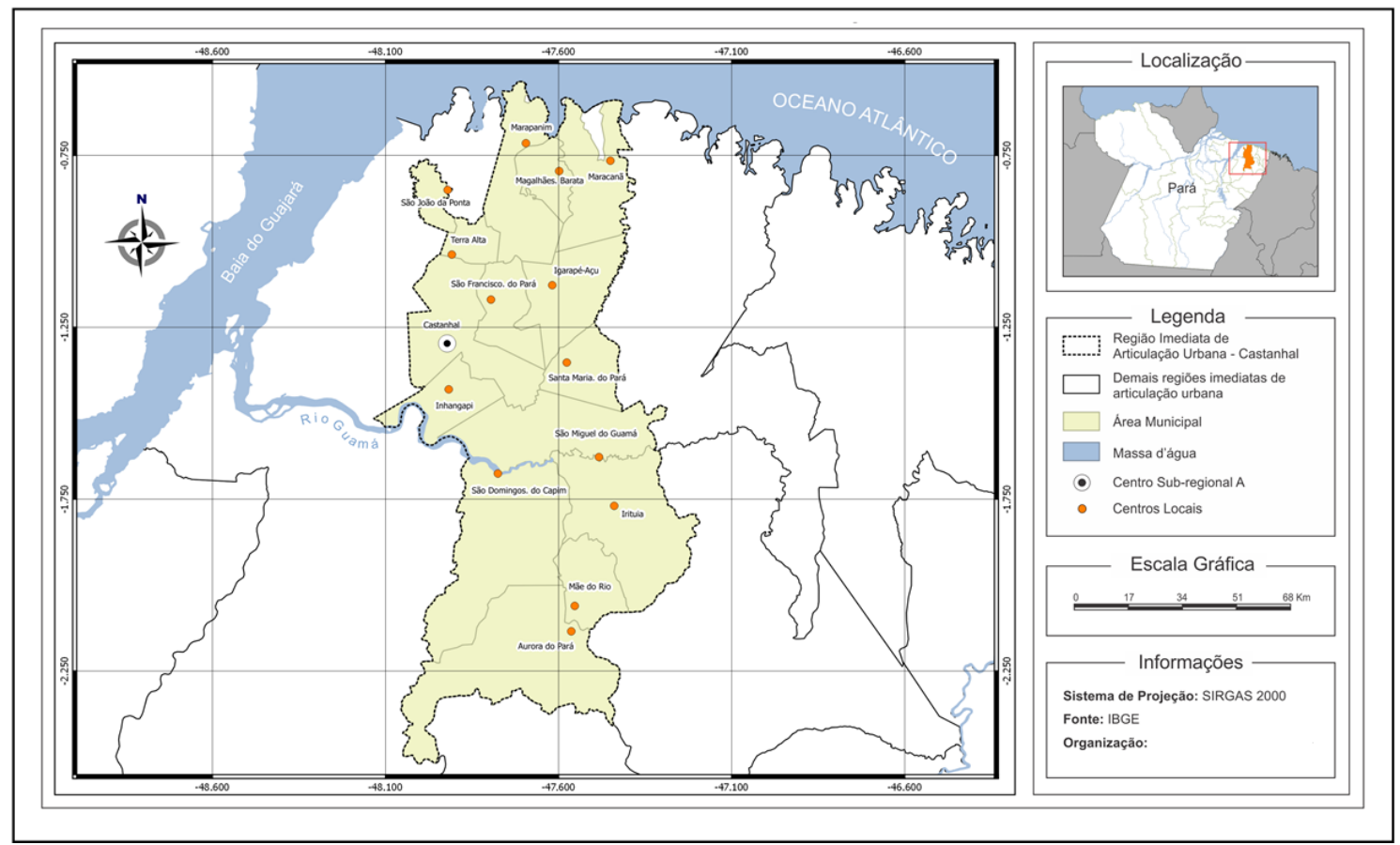

Fonte - Ribeiro (2017).

Castanhal é a cidade que melhor expressa isso, mesmo possuindo proximidade física e relacional com Belém, ela mantém centralidade própria, conformando uma área de influência composta por 15 cidades (IBGE, 2013), nenhuma delas situada a oeste, ou seja, em direção a Belém. A denominação cidade média de entorno metropolitano, imputada a Castanhal por Ribeiro (2017), advém do reconhecimento dessa complexidade, isto é, a conjugação de papéis de cidade média com a imersão em contexto mais amplo, não relativo à metropolização, mas à urbanização regional policêntrica.

\section{CONSIDERAÇÕES FINAIS}

A análise da realidade urbano-regional de Belém do Pará, no norte do Brasil, sob o ponto de vista do processo de urbanização regional policêntrica (SOJA, 2013) e de sua correspondente espacial, a cidade-região, suscita algumas considerações, nesse momento, expostas como finais:

a) As morfologias urbano-regionais estão cada vez mais disseminadas, como atestam diversos estudos acadêmicos, podendo se materializar mesmo em realidades cuja precariedade é característica mais marcante que os avanços técnicos, científicos e informacionais, como no caso de Belém, sendo esse, inclusive, um dos elementos a diferenciar Belém de outros arranjos urbanoregionais, especialmente, aqueles integrantes de países tidos como desenvolvidos. Com isso, não se está dizendo que esses atributos associados à globalização não estejam presentes nestes casos, mas sim que eles acabam por reproduzir desigualdades socioespaciais e, assim, reforçam a

Caminhos de Geografia $\quad$ Uberlândia-MG $\quad$ v. 22, n. $80 \quad$ abr./2021 $\quad$ p. 97-118 Página 115


precariedade. E isso não impede ou se contradiz à configuração de morfologias urbanas complexas transescalares.

Nesses termos, Belém possui, ao mesmo tempo, uma série de semelhanças e diferenças com relação a realidades urbano-regionais mais consolidadas, como a de Los Angeles, nos Estados Unidos, estudada por Edward Soja, ou mesmo a de São Paulo, no Brasil, para citar a forma urbana mais contundente desse tipo no país. Claramente, esses exemplares são mais populosos e extensos, concentram maior riqueza e influenciam áreas muito amplas, caso sejam comparados a Belém. Todavia, como advertido por Scott; Agnew; Soja; Storper (2001) ao tratarem das cidades-regiões, esse conjunto não é homogêneo, ao contrário, é muito diverso no que se refere às suas dimensões e relevância em contextos mais amplos, importando, de fato, para a inclusão nesse conjunto a manifestação de características como complexidade, amplo significado regional, a existência de múltiplas centralidades de expressão regional e a imbricação das escalas do espaço urbano e regional.

b) A urbanização regional policêntrica, da forma como aqui apresentada, não descarta ou se opõe à metrópole e à metropolização, as contêm e ultrapassa, por incorporar dinâmicas, centralidades e ações de origens diversas no plano da rede urbana. Logicamente, a metrópole e os processos dela emanados continuam tendo o protagonismo, entretanto, não são os únicos e a força advinda das outras centralidades é crescente. No caso analisado, da cidade-região de Belém, a quase totalidade dos municípios que a integram possui um crescimento econômico maior que o núcleo metropolitano nos últimos anos. Além disso, a cidade de Castanhal desenvolve papéis de cidade-média e tem em sua própria área de influência o motor de seu fortalecimento, o que não impede sua substancial articulação com o espaço metropolitano e, por conseguinte, sua participação na cidade-região. Suas contribuições, não advindas da metrópole, são importantes componentes da cidade-região. Nesses termos, o processo de urbanização regional policêntrica, enquanto instrumento de interpretação da realidade, apresenta vantagens sobre a concepção de metropolização do espaço, pois admite lógicas mais diversas em sua composição.

c) Em se tratando do exemplo concreto da cidade-região de Belém, enquanto processo, a urbanização regional policêntrica está em permanente construção, sendo assim, muito ainda será feito no sentido da produção dessa realidade, não obstante, o quadro atual já evidencia a sua existência, como pôde ser visto na discussão de fatores a ela associados, como: diversidade de renda e de tipos de assentamentos dos grupos sociais nas antigas e novas áreas dispersas; dispersão dos espaços de consumo; ampliação da escala da dispersão e da configuração das novas periferias; e fortalecimento de outras centralidades (além do núcleo metropolitano) e, conseguinte, diversificação e complexificação dos fluxos.

\section{AGRADECIMENTOS}

Agradecemos à Universidade do Estado do Pará e ao Programa de Pós-Graduação em Geografia pelo suporte às pesquisas que estão na origem dos resultados aqui apresentados. Também ao Programa de Pós-Graduação em Geografia da Universidade Estadual Paulista, Campus de Presidente Prudente, já que o início da investigação se deu com a tese de doutorado. Além disso, também agradecemos, pelo financiamento das pesquisas, à Coordenação de Aperfeiçoamento de Pessoal de Nível Superior - CAPES, ao Conselho Nacional de Desenvolvimento Científico e Tecnológico - CNPq e à Fundação Amazônia de Amparo a Estudos e Pesquisas do Pará FAPESPA.

\section{REFERÊNCIAS}

ASCHER, F. Metapolis: acerca do futuro da cidade. Oeiras/Portugal: Celta, 1998.

CORRÊA, R. L. A rede urbana. São Paulo: Ática, 1989.

CORRÊA, R. L. O espaço urbano. 3 ed. São Paulo: Ática, 1995.

CORRÊA, R. L. Estudos sobre a rede urbana. Rio de Janeiro: Bertrand Brasil, 2006.

DELGADO, J. La urbanización difusa, arquetipo territorial de la ciudad-región. Sociológica, año 18, n. 51, 2003.

Caminhos de Geografia Uberlândia-MG $\quad$ v. 22, n. $80 \quad$ abr./2021 $\quad$ p. 97-118 Página 116


DEMATTEIS, G. Suburbanización y periurbanización: ciudades anglosajonas y ciudades latinas. In: MONCLÚS, F. J. (Ed.). La ciudad dispersa: suburbanización y nuevas periferias. Barcelona: Centre de Cultura Contemporánia de Barcelona, 1998.

FERNANDES, J. H. S.; RIBEIRO, W. O. Interações espaciais e promoção imobiliária como vetores da metropolização do espaço de Marituba/PA. Geo UERJ, Rio de Janeiro, n. 35, 2019. https://doi.org/10.12957/geoueri.2019.39162

FERREIRA, S. B. A expansão dos assentamentos residenciais na llha do Mosqueiro: uma particularidade de dispersão urbana no espaço metropolitano de Belém (PA). 138p. Dissertação (Mestrado em Geografia), Universidade Federal do Pará, Instituto de Filosofia e Ciências Humanas, Programa de Pós-Graduação em Geografia, Belém, 2012.

GOTTMAN, J. A urbanização e a paisagem americana: o conceito de megalópole. In: COHEN, S. B. (Org.). Geografia humana nos Estados Unidos. Rio de Janeiro: Fórum, 1970.

IBGE - Instituto Brasileiro de Geografia e Estatística. Divisão Urbano Regional. Rio de Janeiro: Diretoria de Geociência/ Coordenação de Geografia, 2013.

IBGE - Instituto Brasileiro de Geografia e Estatística. IBGE Cidades [online]. 2020. Disponível em: https://cidades.ibge.gov.br/. Acesso em: 10 de abril de 2020.

IBGE - Instituto Brasileiro de Geografia e Estatística. Regiões de Influência das Cidades 2018. Rio de Janeiro: IBGE, 2020.

KLINK, J. J. A cidade-região: regionalismo e reestruturação no Grande ABC Paulista. Rio de Janeiro: DP\&A, 2001.

LENCIONI, S. Da cidade e sua região à cidade-região. In: SILVA, J. B.; LIMA, L. C.; ELIAS, D. (Orgs.). Panorama da geografia brasileira I. São Paulo: Annablume, 2006.

LENCIONI, S. Para além da urbanização metropolitana: metropolização e regionalização pósmetropolitana. In: FERREIRA, A.; RUA, J.; MATTOS, R. C. O espaço e a metropolização: cotidiano e ação. Rio de Janeiro: Consequência, 2017.

MAGALHÃES, F. N. C. Da metrópole à cidade-região: na direção de um novo arranjo espacial metropolitano? Revista Brasileira de Estudos Urbanos e Regionais, v. 10, n. 2 / novembro 2008. https://doi.org/10.22296/2317-1529.2008v10n2p9

MARTINS, J. S. Exclusão social e a nova desigualdade. São Paulo: Paulus, 1997.

MEIRA FILHO, A. Mosqueiro: ilhas e vilas. Belém: Grafisa, 1978.

MONCLÚS, F. J. Suburbanización y nuevas periferias. Perspectivas geográfico-urbanísticas. In: MONCLÚS, F. J. (Ed.). La ciudad dispersa. Barcelona: Centro de Cultura Contemporânea de Barcelona, 1998.

MOREIRA, E. Belém e sua expressão geográfica. Belém: Imprensa Universitária, 1966.

MOURA, R. Arranjos urbano-regionais no Brasil: uma análise com foco em Curitiba. 242p. Tese (Doutorado em Ciências da Terra), Universidade Federal do Paraná, Programa de Pós-Graduação em Geografia, Curitiba. 2009.

PENTEADO, A. R. Belém: estudo de geografia urbana ( $2^{\circ}$ volume). Belém: UFPA, 1968.

PORTO-GONÇALVES, C. W. Amazônia, Amazônias. 2 ed. São Paulo: Contexto, 2008.

RIBEIRO, W. O. Ordem e desordem do território turístico: a chegada do estranho e os conflitos de territorialidades na orla oeste de Mosqueiro, Belém/PA. 138p. Dissertação (Mestrado em Geografia), Universidade Federal do Pará, Programa de Pós-graduação em Geografia, Belém. 2007. ttps://doi.org/10.17551/2358-1778/geoamazonia.n2v1p123-143

RIBEIRO, W. O. Territórios, territorialidades e reordenamentos das práticas turísticas nas praias de rio da orla oeste de Mosqueiro, Belém/PA. Revista GeoAmazônia, Belém, n. 2, v. 01, p. 123 - 143, jan./jun. 2014.

RIBEIRO, W. O. Interações espaciais na rede urbana do Nordeste do Pará: particularidades regionais e diferença de Bragança, Capanema e Castanhal. 356p. Tese (Doutorado em Geografia) - 
Programa de Pós-Graduação em Geografia, Universidade Estadual Paulista, Presidente Prudente. 2017.

RIBEIRO, W. O. Dispersão metropolitana e novas formas urbano-regionais: uma proposta para o reconhecimento e a delimitação da cidade-região de Belém. Ateliê Geográfico - Goiânia-GO, v. 12, n. 1, p. 132-154, 2018. https://doi.org/10.5216/ag.v12i1.43695

SANTOS, K. P. A produção do espaço urbano e vida cotidiana: uma análise nos diferentes assentamentos urbanos em Castanhal-PA. 166p. Dissertação (Mestrado em Geografia), Universidade Federal do Pará, Programa de Pós-graduação em Geografia, Belém. 2019.

SANTOS, M. A natureza do espaço: espaço e tempo; razão e emoção. 4 ed. São Paulo: Edusp, 2009.

SARGES, M. N. Belém: riquezas produzindo a Belle Époque (1870-1912). 3 ed. Belém: Paka-Tatu, 2010.

SASSEN, S. El reposicionamiento de las ciudades y regiones urbanas en una economía global: ampliando las opciones de políticas y gobernanza. EURE, Santiago de Chile, v.33, n.100, p.9-34, dic. 2007. https://doi.org/10.4067/S0250-71612007000300002

SCOTT, A. J.; AGNEW, J.; SOJA, E. W.; STORPER, M. Cidades-regiões globais. Espaço e Debates, São Paulo, n.41, p.11-25, 2001.

SOJA, E. W. Postmetrópolis: estudios críticos sobre las ciudades y las regiones. Madrid: Traficantes de Sueños, 2008.

SOJA, E. W. Para além de postmetropolis. Rev. UFMG, Belo Horizonte, v. 20, n.1, p.136-167, jan./jun. 2013. https://doi.org/10.35699/2316-770X.2013.2678

TRINDADE JÚNIOR, S. C. A cidade dispersa: os novos espaços de assentamentos em Belém e a reestruturação metropolitana. 395p. Tese (Doutorado em Geografia) - FFLCH/USP, São Paulo. 1998.

Recebido em: 12/05/2020

Aceito para publicação em: 14/08/2021 